\title{
Influence of Dietary Phosphorus and Zinc Levels on Whole Body Mineral, Liver Mineral, and Liver Vitamin-C Contents of Fingerling Rainbow Trout, Oncorhynchus mykiss
}

\author{
M. S. Alam SARKER ${ }^{1 *}$ AND ShUichi SATOH ${ }^{2}$ \\ ${ }^{1}$ School of Agriculture and Rural Development, Bangladesh Open University, Gazipur, Bangladesh \\ ${ }^{2}$ Laboratory of Fish Nutrition, Department of Marine Biosciences, Tokyo University of Marine \\ Science and Technology, Minato, Tokyo 108-8477, Japan
}

\begin{abstract}
A laboratory based $2 \times 2$ factorial experiment was conducted to investigate the influence of dietary phosphorus and zinc levels on whole body mineral, liver mineral, and liver vitamin-C contents of fingerling rainbow trout for 21 weeks. Two levels of phosphorus (19 and $30 \mathrm{mg} \mathrm{g}^{-1}$ ) and two levels of zinc (55 and $100 \mathrm{\mu} \mathrm{g} \mathrm{g}^{-1}$ ) in the dry diets were tested. Duplicate tanks of 30 rainbow trout (average weight $1.56 \pm 0.24 \mathrm{~g}$ ) per $60 \mathrm{~L}$ glass tank were fed experimental diets three times a day to satiation level in 15 to $24^{\circ} \mathrm{C}$ water temperature. The result of the present study demonstrated that dietary zinc supplementation significantly influenced the whole body zinc and liver copper contents in fingerling rainbow trout where as additional phosphorus did not show any significant difference. Zinc supplementation significantly influenced the liver vitamin-C contents of the fish. Hence it is clear that zinc supplementation is necessary in fingerling rainbow trout feed. Further studies in this area are needed broadly.
\end{abstract}

Key words: Phosphorus, zinc, whole body, liver mineral, liver vitamin-C, rainbow trout

\section{INTRODUCTION}

Rainbow trout belongs to the family Salmonidae. This species was originally taxonomically linked with the Atlantic or Eurasian trouts of the genus Salmo. The natural geographical distribution of rainbow trout includes freshwater systems along the eastern Pacific Ocean, mainly west of the Rocky Mountains, from the northwest Mexico the Kuskokwim River in southwestern Alaska. In Asia, rainbow trout are most abundant on the Kamchatka Peninsula. Rainbow trout have been introduced widely outside their natural range in suitable habitat throughout North America and other parts of the world, such as South America, Europe, southern Asia, Japan, Africa and Oceania (Groot 1996, Scott and Crossman 1975).

Rainbow trout has important commercial and sport value. Their simple requirements for incubation under artificial conditions have made it possible to introduce this fish to many new areas in the world. In the natural environment rainbow trout feed on various invertebrates and plankton, larger crustaceans, fish, insects, snails, and leeches. Nutritional requirements of rainbow trout have

* Corresponding author: Associate Professor, SARD, BOU; Tel. 88-02-9291101-4/331; Fax: 88-02-9291122;

Mobile: 01718630776; E-mail: sarkeralam@yahoo.com

(C) 2006 School of Agriculture and Rural Development, Bangladesh Open University, All rights reserved. 
been well studied (NCR 1993). Rainbow trout is the most widely farmed trout in the world and one of the few species of fish that may be regarded as truly domesticated.

Like in other animals, $\mathrm{P}$ is an essential nutrient for fish, being a major constituent of skeletal tissues, nucleic acids DNA and RNA, energy transport compounds like ATP, and of phospholipids in cell membranes (Lall 1991). Dietary phosphorus (P) is essential for optimum growth and metabolism of fish. It is the most important mineral needed by fish, since its requirement and functions are superior to that of any other mineral element (NCR 1993; Satoh et al. 2002).

Information on the metabolism, excretion and utilization of dietary $P$ in fish is limited (Lall 1991). However, the necessity of $P$ supplementation in a fish meal-based diet has been reported for the post juvenile stage (Masumoto 2002). Fishmeal is the source of most dietary $P$ in fish diets, wherein it exists as hydroxyapatite and/or tricalcium phosphate (TCP). Due to its structural complexity, $\mathrm{P}$ and $\mathrm{Ca}$ from TCP have been reported to be less available to some fish species (Takamtsu et al. 1975, Shitanda et al. 1979, Watanabe et al. 1980).

Zinc (Zn) is required in the diet as it is more efficiently absorbed than the waterborne Zn (NRC 1993). It is essential for growth, development and maintenance of healthy bones (Yamaguchi 1998), and functions as a cofactor of several enzymes and an integral part of about 20 metalloenzymes such as alkaline phosphatase (ALP), alcohol dehydrogenase and carbonic anhydrase (Hambidge et al. 1986, Watanabe et al. 1997). The availability of $\mathrm{Zn}$ is dependent on the type of the diet, protein source and the chemical form of the element. Requirement of fish for $\mathrm{Zn}$ was reported to be substantially higher when fed with practical diets (fishmeal based diets) compared with purified diets (Ketola 1979; Gatlin and Wilson 1984, Hardy and Shearer 1985, Satoh et al. 1987a,b). Zinc deficiency affects the digestibility of protein and carbohydrate because of the reduced activity of carboxypeptidase (Ogino and Yang 1978). Zinc has close linkage with ascorbic acid which is important for fish reproduction. Liver is an important tissue for deposition of trace elements and also good indicator of mineral status in fish.

Therefore, the present study aimed to investigate the influence of dietary phosphorus level, zinc level and their interaction on whole body mineral, liver mineral, and liver vitamin- $\mathrm{C}$ contents of fingerling rainbow trout.

\section{MATERIALS AND METHODS}

\section{Experimental diets and design}

Practical diets (fishmeal based diets) were formulated to contain 19 and $30 \mathrm{~g} \mathrm{~kg}^{-1} \mathrm{P}$ employing monocalcium phosphate and 54 and $100 \mathrm{~g} \mathrm{~kg}^{-1} \mathrm{Zn}$ using inorganic zinc sulphate (Table 1). The diets were labeled according to factors (P and Z) and levels as P0Z0, P0Z1, P1Z0 and P1Z1. The experimental diets were formulated to be isocaloric and isonitrogenous. The carbohydrate sources and binders were wheat flour and pregelatinized starch, and the lipid source was pollock liver oil and soybean oil. The formulation and composition of experimental diets are presented in Table 1. The experiment was conducted in a $2 \times 2$ factorial design with the factors 'dietary phosphorus level 'and 'supplemental Zn level'.

The minerals mixture used in this study was the modified form of Ogino salt mixture (Ogino et al. 1979). The diets were pelleted using the laboratory pelletizer (AEZ12M, Hiraga-Seikakusho, Kobe, Japan), dried in a vacuum freeze-drier (RLE-206, Kyowa Vacuum Tech., Saitama, Japan), and stored at $4^{\circ} \mathrm{C}$ until use.

The proximate composition and minerals contents of the experimental diets used in this study are shown in Table 2 and Table 3, respectively. The diets were prepared with 57\% fish meal (FM) as the sole protein source. Ingredients used in the test diets were selected taking into consideration the amino acid balance of the whole protein sources (Watanabe et al. 1993). 
Table 1. Formulation and composition of the experimental diets

\begin{tabular}{|c|c|c|c|c|}
\hline \multirow{2}{*}{ Ingredients (\%) } & \multicolumn{4}{|c|}{ Diets } \\
\hline & P0Z0 & P0Z1 & P1Z0 & P1Z1 \\
\hline "Jack mackerel meal & 57 & $\overline{57}$ & 57 & 57 \\
\hline Wheat flour & 20 & 20 & 20 & 20 \\
\hline Pregelatinized starch & 5 & 5 & 5 & 5 \\
\hline Pollock liver oil & 4 & 4 & 4 & 4 \\
\hline Soybean oil & 5 & 5 & 5 & 5 \\
\hline Mineral premixture $^{a}$ & 0 & 1 & 0 & 1 \\
\hline Zn free mineral mixture ${ }^{b}$ & 0 & 1 & 0 & 1 \\
\hline $\mathrm{Ca}\left(\mathrm{H}_{2} \mathrm{PO}_{4}\right)_{2}$ & 0 & 0 & 4 & 4 \\
\hline Vitamin premixture $^{\mathrm{c}}$ & 1.5 & 1.5 & 1.5 & 1.5 \\
\hline Choline chloride & 0.5 & 0.5 & 0.5 & 0.5 \\
\hline Vitamin E (50\%) & 0.1 & 0.1 & 0.1 & 0.1 \\
\hline Cellolose & 5.9 & 5.9 & 5.9 & 5.9 \\
\hline
\end{tabular}

${ }^{a}$ Mineral premixture (\%) $-\mathrm{NaCl} 5.0, \mathrm{Mg} \mathrm{SO}_{4} \cdot 7 \mathrm{H}_{2} \mathrm{O} 74.5, \mathrm{FeC}_{6} \mathrm{H}_{5} \mathrm{O}_{7} \cdot 7 \mathrm{H}_{2} \mathrm{O}$ 12.5, Trace element mix. ${ }^{a^{*}}$ 5.0 Cellulose 3.0

$\mathrm{a}^{*}(\%)-\mathrm{ZnSO}_{4} \cdot 7 \mathrm{H}_{2} \mathrm{O} 353, \mathrm{MnSO}_{4} \cdot 5 \mathrm{H}_{2} \mathrm{O} 162, \mathrm{CuSO}_{4} \cdot 5 \mathrm{H}_{2} \mathrm{O} 31, \mathrm{AlCl}_{3} \cdot 6 \mathrm{H}_{2} \mathrm{O} 10, \mathrm{CoCl} \cdot 6 \mathrm{H}_{2} \mathrm{O} 1, \mathrm{KIO}_{3} 3$, Cellulose 440.

${ }^{b} \mathrm{Zn}$ free mineral mixture (\%)- $\mathrm{NaCl} 5.0, \mathrm{Mg} \mathrm{SO}_{4} \cdot 7 \mathrm{H}_{2} \mathrm{O} 74.5, \mathrm{FeC}_{6} \mathrm{H}_{5} \mathrm{O}_{7} \cdot 7 \mathrm{H}_{2} \mathrm{O} 12.5$, Zn-free mineral mix. ${ }^{\mathrm{b}^{\star}} 5.0$ ' Cellulose 3.0

$\mathrm{b}^{*}(\%)-\mathrm{AlCl}_{3} \cdot 6 \mathrm{H}_{2} \mathrm{O} 10, \mathrm{CoCl} \cdot 6 \mathrm{H}_{2} \mathrm{O} 1, \mathrm{KIO}_{3} 3$, Cellulose 986.

${ }^{c}$ Vitamin mix (\%)-Thiamine hydrochloride 6, Riboflavin 10, Pyridoxine hydrochloride 4, Cyanocobalamin 0.01 , Ascorbic acid 500, Niacin 40, Ca-pantothenate, 10, Inositol 200, Biotin 0.6, Folic acid 1.5, p-aminobenzoic acid

5 , Vitamin $\mathrm{K}_{3} 5$, Vitamin A acetate $4000 \mathrm{IU}$, Vitamin $\mathrm{D}_{3} 4000 \mathrm{IU}$.

Table 2. Proximate composition of the experimental diets (dry matter basis)

\begin{tabular}{lcccc}
\hline \multicolumn{1}{c}{ Parameters } & \multicolumn{3}{c}{ Diets } \\
\cline { 2 - 5 } & P0Z0 & P0Z1 & P1Z0 & P1Z1 \\
\hline \hline Moisture (\%) & 4.5 & 4.5 & 3.0 & 4.5 \\
Crude ash (\%) & 11.1 & 10.8 & 13.7 & 13.6 \\
Crude protein (\%) & 44.9 & 44.7 & 45.5 & 45.2 \\
Crude lipid (\%) & 16.6 & 16.7 & 16.6 & 16.9 \\
Gross energy (kcal/g) & 5.2 & 5.2 & 5.0 & 5.0 \\
\hline
\end{tabular}

Table 3. Mineral contents of the experimental diets (dry matter basis)

\begin{tabular}{lcccc}
\hline \multirow{2}{*}{ Macro elements } & \multicolumn{3}{c}{ Diets } \\
\cline { 2 - 5 } & P0Z0 & P0Z1 & P1Z0 & P1Z1 \\
\hline \hline $\mathrm{P}(\mathrm{mg} / \mathrm{g})$ & 1914 & 19.49 & 30.30 & 30.09 \\
$\mathrm{Ca}(\mathrm{mg} / \mathrm{g})$ & 28.03 & 30.19 & 34.76 & 35.20 \\
$\mathrm{Mg}(\mathrm{mg} / \mathrm{g})$ & 3.00 & 3.05 & 3.00 & 2.97 \\
$\mathrm{Na}(\mathrm{mg} / \mathrm{g})$ & 3.86 & 3.41 & 3.58 & 3.82 \\
$\mathrm{~K}(\mathrm{mg} / \mathrm{g})$ & 4.71 & 3.75 & 4.32 & 4.50 \\
Trace elements & & & & \\
$\mathrm{Zn}(\mu \mathrm{g} / \mathrm{g})$ & 54.54 & 103.24 & 55.85 & 96.07 \\
$\mathrm{Mn}(\mu \mathrm{g} / \mathrm{g})$ & 40.44 & 40.71 & 41.18 & 40.62 \\
$\mathrm{Fe}(\mu \mathrm{g} / \mathrm{g})$ & 345.54 & 341.90 & 352.17 & 348.24 \\
$\mathrm{Cu}(\mu \mathrm{g} / \mathrm{g})$ & 7.04 & 7.05 & 10.63 & 8.35 \\
\hline
\end{tabular}

\section{Fish rearing and feeding methods}

Eyed eggs of rainbow trout were obtained from Fuji Trout Farm of Shizuoka Prefecture Fisheries Experiment Station and hatched under laboratory conditions at the Tokyo University of Marine Science and Technology. Fish with an average body weight of $1.56 \pm 0.24 \mathrm{~g}$ were randomly selected from stock and distributed into $60 \mathrm{~L}$ tanks at a density of 30 fish per tank. Triplicate groups were assigned to each experimental diet and the feeding was conducted for 21 weeks. The fish were hand fed three times a day, 6 days a week to apparent satiation level. The tanks had a continuous water supply at a rate of 0.6-1.0 $\mathrm{l} / \mathrm{min}$ and the temperature was 15 to $24^{\circ} \mathrm{C}$. 


\section{Sampling and analytical methods}

The fish were starved for $24 \mathrm{~h}$ before being individually weighed at the initial day and every 21 days of the experimental period after being anesthetized with ethylene glycol monophenyl ether (300 ppm). At the same time 5 fish were randomly sampled from each tank and stored at $-20^{\circ} \mathrm{C}$ for analyses.

Proximate composition and chemical analyses of the diets and fish whole body samples were made in three replicates. Proximate analysis of the samples were performed according to Satoh et al. $(1987,1996)$ as follows: moisture content was measured gravimetrically, crude ash content was determined by incinerating a known amount of sample in an electric muffle furnace (Yamato, FA21) at $600{ }^{\circ} \mathrm{C}$ for 8 hours, crude protein was analyzed using the Kjeltec Auto Sampler System 1035/38 (Netherland). Crude lipid was measured by following the method of Folch et al. (1957). Samples for minerals were digested in nitric acid using the MLS-1200 Mega Microwave Digestion System (Italy), cooled in flowing water for 30 minutes, and diluted with de-ionized water to the required volume. Concentration of each element was measured by a Polarized Zeeman Atomic Absorption Spectrophotometer (Hitachi Z-5010, Tokyo, Japan) except for phosphorus which was analyzed by a visible light spectrophotometry (Shimadzu, UV 265 FW, Kyoto, Japan) at 750nm.

\section{Condition Factor}

Condition factor was calculated as $\mathrm{K}=($ body weight, $\mathrm{g}) * 100 /(\text { body length, } \mathrm{cm})^{3}$.

\section{Vitamin-C assay (Ascorbic acid)}

The total liver vitamin-C (ascorbic acid) in rainbow trout was analyzed according to the method described by Dabrowski and Hinterleitner (1989). The ascorbate mono phosphate levels in liver vitamin-C was determined by high performance liquid chromatography (HPLC) with ultra viotel (UV) detection modified from the method described by Bushway et al. (1988).

\section{Statistical analyses}

Statistical analyses were performed using either one-way or two-way ANOVA with SYSTAT 8.0 software (SPSS Inc. 1998). Differences between treatments were evaluated by Tukey's test. The level of significance was set at $P<0.05$ for all tests.

\section{RESULTS AND DISCUSSION}

Weight gain of the fish did not show any significant difference among treatments of Zn throughout the culture period. Also SGR, FCR and TGC were not significantly affected by the treatment while additional $\mathrm{P}$ reduced significantly (Table 4). Phosphorus and $\mathrm{Zn}$ levels had interaction effect on FCR (Table 4).

Table 4. Growth and feed performance of the experimental diets for 21 weeks

\begin{tabular}{llllll}
\hline Diet group & Weight gain & SGR $^{1}$ (\%/day) & FCR $^{2}$ & TGC $^{3}$ & Condition factor \\
\hline \hline P0Z0 & $73.62^{\mathrm{a}}$ & $2.62^{\mathrm{a}}$ & $0.97^{\mathrm{a}}$ & $0.001125^{\mathrm{a}}$ & $1.161^{\mathrm{a}}$ \\
P0Z1 & $72.61^{\mathrm{a}}$ & $2.62^{\mathrm{a}}$ & $0.96^{\mathrm{a}}$ & $0.001118^{\mathrm{a}}$ & $1.153^{\mathrm{a}}$ \\
P1Z0 & $62.88^{\mathrm{b}}$ & $2.52^{\mathrm{b}}$ & $1.01^{\mathrm{b}}$ & $0.001047^{\mathrm{b}}$ & $1.162^{\mathrm{a}}$ \\
P1Z1 & $59.54^{\mathrm{b}}$ & $2.48^{\mathrm{b}}$ & $1.02^{\mathrm{b}}$ & $0.001021^{\mathrm{b}}$ & $1.125^{\mathrm{a}}$ \\
P level & $<0.05$ & $<0.05$ & $<0.05$ & $<0.05$ & $\mathrm{NS}$ \\
Zn level & NS & NS & NS & NS & NS \\
P level $\times$ Zn level & NS & NS & $<0.05$ & NS & NS \\
\hline
\end{tabular}

${ }^{1}$ Specific growth rate; ${ }^{2}$ Feed conversion ratio. ${ }^{3}$ Thermal-unit growth coefficient;

* Values in the same column not sharing a common superscript letter are significantly different $(P<0.05)$. NS = Not significant.

The results of growth performance and feed utilization suggest that different levels of $\mathrm{Zn}$ had no influence on the feed intake and growth performance of fish. In addition, the results represent the stated parameters not to be potential and appropriate indices to assess $\mathrm{P}$ and $\mathrm{Zn}$ level differences. Similar results were obtained by Hardy and Shearer (1985), and Li and Robinson (1996). 
Furthermore, Tan and Mai (2001) reported that growth of abalone was significantly affected by the dietary $\mathrm{Zn}$ levels. Based on the present results, weight gain may not be an appropriate index of $\mathrm{Zn}$ bioavailability in rainbow trout, but tissue $\mathrm{Zn}$ content could potentially be used to assess treatment differences.

Carcass proximate composition of rainbow trout at start and end of the experiment is presented in the Table 5. This revealed influence of $\mathrm{Zn}$ supplementation on crude ash though not remarkable while $\mathrm{P}$ supplementation showed significant different on whole body crude ash contents.

Table 5. Proximate carcass composition of fish at start $(n=30)$ and end $(n=12)$ of the experiment fed experimental diets

\begin{tabular}{ccccc}
\hline Initial/Diet group & Moisture (\%) & Crude ash (\%) & Crude protein (\%) & Crude lipid (\%) \\
\hline \hline Initial & 76.36 & 2.63 & 15.36 & 5.88 \\
P0Z0 & 67.37 & $1.97^{\mathrm{b}}$ & 16.46 & 14.35 \\
P0Z1 & 67.33 & $2.03^{\mathrm{ab}}$ & 16.26 & 14.33 \\
P1Z0 & 68.58 & $2.36^{\mathrm{a}}$ & 16.28 & 12.71 \\
P1Z1 & 68.58 & $2.17^{\mathrm{ab}}$ & 16.31 & 13.22 \\
P level & NS & $<0.05$ & $\mathrm{NS}$ & NS \\
Zn level & NS & NS & NS & NS \\
P level $\times$ Zn level & NS & NS & NS & NS \\
\hline
\end{tabular}

Values in the same column not sharing a common superscript letter are significantly different $(P<0.05)$. NS $=$ Not significant.

Whole body is an indicator to quantify Zn status in animals (Wekell et al. 1986). Insignificant variations were observed among different treatments of both $\mathrm{P}$ and $\mathrm{Zn}$ in the case of whole body $\mathrm{P}$, $\mathrm{Ca}, \mathrm{Mg}, \mathrm{Na}, \mathrm{K}$ and $\mathrm{Mn}$ contents (Table 6). Conversely, whole body $\mathrm{Zn}$ content was found to increase significantly $(P<0.05)$ in the treatments with higher $\mathrm{Zn}$ supplementation (Table 6). Supplementation of $\mathrm{P}$ also increased the whole body Fe significantly.

Table 6. Whole body mineral contents of fish at start $(n=30)$ and end $(n=12)$ of the experiment fed experimental diets

\begin{tabular}{lccccccccc}
\hline $\begin{array}{c}\text { Initial/Diet } \\
\text { group }\end{array}$ & $\begin{array}{c}\mathbf{P} \\
(\mathbf{m g} / \mathbf{g})\end{array}$ & $\begin{array}{c}\mathrm{Ca} \\
(\mathbf{m g} / \mathbf{g})\end{array}$ & $\begin{array}{c}\mathbf{M g} \\
(\mathbf{m g} / \mathbf{g})\end{array}$ & $\begin{array}{c}\mathbf{N a} \\
(\mathbf{m g} / \mathbf{g})\end{array}$ & $\begin{array}{c}\mathrm{K} \\
(\mathbf{m g} / \mathbf{g})\end{array}$ & $\begin{array}{c}\mathbf{Z n} \\
(\boldsymbol{\mu} \mathbf{g} / \mathbf{g})\end{array}$ & $\begin{array}{c}\mathrm{Fe} \\
(\boldsymbol{\mu} \mathbf{g} / \mathbf{g})\end{array}$ & $\begin{array}{c}\mathbf{C u} \\
(\boldsymbol{\mu} \mathbf{g} / \mathbf{g})\end{array}$ & $\begin{array}{c}\mathbf{M n} \\
(\boldsymbol{\mu} \mathbf{g} / \mathbf{g})\end{array}$ \\
\hline \hline Initial & 5.32 & 5.62 & 0.34 & 0.99 & 3.69 & 25.6 & 12.2 & 0.67 & 1.35 \\
P0Z0 & 4.43 & 3.94 & 0.33 & 0.7 & 3.56 & $15.2^{\mathrm{ab}}$ & 9.61 & 1.00 & 1.36 \\
P0Z1 & 4.29 & 3.48 & 0.31 & 0.67 & 3.73 & $23.5^{\mathrm{a}}$ & 9.01 & 1.11 & 0.99 \\
P1Z0 & 4.98 & 4.87 & 0.35 & 0.72 & 3.65 & $13.7^{\mathrm{b}}$ & 11.5 & 1.25 & 1.16 \\
P1Z1 & 4.49 & 3.89 & 0.32 & 0.64 & 3.63 & $21.9^{\mathrm{a}}$ & 10.3 & 1.04 & 1.11 \\
P level & $\mathrm{NS}$ & $\mathrm{NS}$ & $\mathrm{NS}$ & $\mathrm{NS}$ & $\mathrm{NS}$ & $\mathrm{NS}$ & $<0.05$ & $\mathrm{NS}$ & $\mathrm{NS}$ \\
Zn level & $\mathrm{NS}$ & $\mathrm{NS}$ & $\mathrm{NS}$ & $\mathrm{NS}$ & $\mathrm{NS}$ & $<0.05$ & $\mathrm{NS}$ & $\mathrm{NS}$ & $\mathrm{NS}$ \\
P level $\times$ Zn level & $\mathrm{NS}$ & $\mathrm{NS}$ & $\mathrm{NS}$ & $\mathrm{NS}$ & $\mathrm{NS}$ & $\mathrm{NS}$ & $\mathrm{NS}$ & $\mathrm{NS}$ & $\mathrm{NS}$ \\
\hline
\end{tabular}

Values in the same column not sharing a common superscript letter are significantly different $(P<0.05), \quad N S=$ Not significant.

Higher whole body Zn content treatments with higher Zn supplementation in this study is an agreement with the other study in Atlantic Salmon and rainbow trout (Maage and Julshamn 1993, Apines et al. 2001). Zinc concentration of abalone also increased linearly with dietary Zn (Tan and Mai 2001).

Both dietary $P$ and $Z n$ levels did not show any significant difference $(P>0.05)$ in case of liver $P$, $\mathrm{Ca}, \mathrm{Mg}, \mathrm{Na}, \mathrm{K}, \mathrm{Zn}, \mathrm{Fe}$ and $\mathrm{Mn}$ contents (Table 7). On the other hand, liver Cu content was found to increase significantly $(\mathrm{P}<0.05)$ in the treatments with higher $\mathrm{Zn}$ supplementation (Table 7$)$. This result indicates that $\mathrm{Zn}$ has a close relation with $\mathrm{Cu}$. 
Table 7. Liver mineral contents of fish at the end of the experiment fed experimental diets $(n=12)$

\begin{tabular}{lccccccccc}
\hline $\begin{array}{l}\text { Initial/Diet } \\
\text { group }\end{array}$ & $\begin{array}{c}\mathbf{P} \\
(\mathbf{m g} / \mathbf{g})\end{array}$ & $\begin{array}{c}\mathbf{C a} \\
(\mathbf{m g} / \mathbf{g})\end{array}$ & $\begin{array}{c}\mathbf{M g} \\
(\mathbf{m g} / \mathbf{g})\end{array}$ & $\begin{array}{c}\mathbf{N a} \\
(\mathbf{m g} / \mathbf{g})\end{array}$ & $\begin{array}{c}\mathbf{K} \\
(\mathbf{m g} / \mathbf{g})\end{array}$ & $\begin{array}{c}\mathbf{Z n} \\
(\boldsymbol{\mu} \mathbf{g} / \mathbf{g})\end{array}$ & $\begin{array}{c}\mathbf{F e} \\
(\boldsymbol{\mu} \mathbf{g} / \mathbf{g})\end{array}$ & $\begin{array}{c}\mathbf{C u} \\
(\boldsymbol{\mu} \mathbf{g} / \mathbf{g})\end{array}$ & $\begin{array}{c}\mathbf{M n} \\
(\boldsymbol{\mu} \mathbf{g} / \mathbf{g})\end{array}$ \\
\hline \hline P0Z0 & 2.86 & 0.02 & 0.18 & 1.03 & 4.40 & 20.14 & 97.21 & $92.38^{\mathrm{b}}$ & 0.77 \\
P0Z1 & 2.88 & 0.02 & 0.19 & 1.05 & 4.04 & 24.88 & 94.25 & $103.69^{\mathrm{a}}$ & 0.77 \\
P1Z0 & 3.14 & 0.01 & 0.19 & 1.01 & 4.22 & 21.03 & 81.45 & $77.51^{\mathrm{b}}$ & 0.68 \\
P1Z1 & 2.92 & 0.03 & 0.19 & 1.06 & 4.39 & 21.75 & 89.23 & $101.81^{\mathrm{a}}$ & 0.83 \\
P level & NS & NS & NS & NS & NS & NS & NS & NS & NS \\
Zn level & NS & NS & NS & NS & NS & NS & NS & $<0.05$ & NS \\
P level $\times$ Zn level & NS & NS & NS & NS & NS & NS & NS & NS & NS \\
\hline
\end{tabular}

Values in the same column not sharing a common superscript letter are significantly different $(P<0.05)$, NS = Not significant.

The liver vitamin-C (Ascorbic acid) increased significantly $(P<0.05)$ with the additional $Z n$ in the diet of fingerling rainbow trout (Fig. 1). On the other hand, supplemental $P$ did not influence liver vitamin- $C$ contents in the fingerling rainbow trout. This result indicates a close relation of $\mathrm{Zn}$ with ascorbic acid.

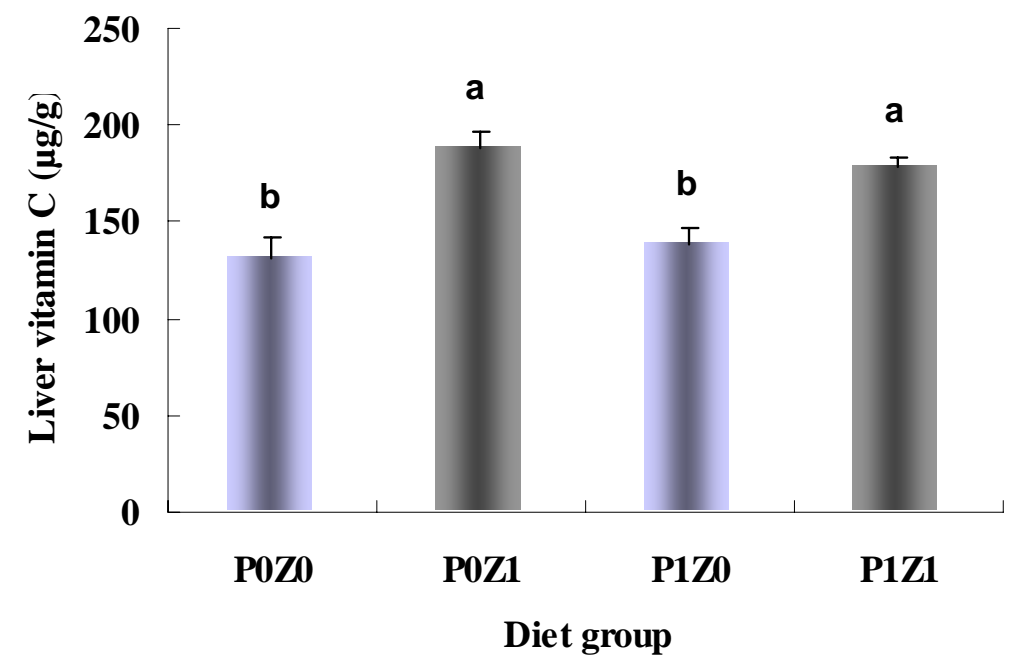

Fig. 1. Effect of dietary $P$ and $Z n$ levels on liver vitamin $C$ contents of rainbow trout at the end of the experiment $(n=12)$ fed experimental diets for 21weeks

\section{CONCLUSION}

The overall results of the present study demonstrated that $P$ supplementation in the diet did not show any positive effect on growth, whole body mineral and liver mineral contents in fingerling rainbow trout while liver vitamin- $C$ contents increased significantly with the additional $\mathrm{Zn}$. On the other hand, additional dietary Zn significantly influenced whole body and liver mineral contents, hence $\mathrm{Zn}$ supplementation is needed. Further study in this area with different sized and aged rainbow trout will corroborate these findings.

\section{ACKNOWLEDGEMENT}

The authors express their gratitude to the Japanese Ministry of Education, Culture, Sports, Science and Technology (MEXT) for the scholarship grant extended to Md. Shah Alam Sarker. We also wish to express our thanks to the Okutama Branch of the Tokyo Fisheries Experimental Station for 
providing the eyed-egg rainbow trout. This study was partly supported by the Grants-in-Aid for scientific research of MEXT and the Grant of the Fisheries Agency of Japan.

\section{LITERATURE CITED}

Apines, M. J., Satoh, S., Kiron, V., Watanabe, T., Nasu, N. and Fugita, S. 2001. Bioavailability of amino acid chelated and glass embaded zinc to rainbow trout, Oncorhynchus mykiss, fingerlings. Aquacult. Nutri. 7, 221-228.

Bushway, R. J., King, J. M. Perkins, B. and Krisman, M. 1988. High performance liquid chromatographic determination of ascorbic acid in fruits, vegetables, and juices. J. Liquid Chrom. 11, 3415-3423.

Dabrowski and Hinterleitner, 1989. Simultaneous analysis of ascorbic acid, dehydroascorbic acid and ascorbic sulphate in biological mineral. Analyst. 114, 32-87.

Folch, J., Lees, M. and Stanley, G. H. S. 1957. A simple method for isolation and purification of total lipid from animal tissues. J. Biol. Chem. 226, 45-63.

Gatlin, D. M. III and Wilson, R. P. 1984. Zinc supplementation of practical channel catfish diets. Aquaculture 41, 31-36.

Groot, C. 1996. Salmonid life histories. In: Pennel, W. and Barton, B.A. (eds). Principles of salmonid culture. Elseiver, Amsterdam, pp. 97-230.

Hambidge, K. M., Casey, C. E. and Krebs, N. S. 1986. Zinc. In: Trace Element in Human and Animal Nutrition, Vol. 2., 5th edn (Mertz,W. ed.), pp. 1-137. Academic Press, San Diego.

Hardy, R. W. and Shearer, K. D. 1985. Effect of dietary calcium phosphate and zinc supplementation on whole body zinc concentration of rainbow trout (Salmo gairdneri) . Can. J. Fish. Aquat. Sci. 42, 181-184.

Ketola, H. G. 1979. Influence of dietary zinc on cataracts in rainbow trout (Salmo gairdneri). J. Nutr. 109, 965-969.

Lall, S. P. 1991. Digestibility, metabolism and excretion of dietary phosphorus in fish. In: Cowey CB, Cho CY (eds). Nutritional Strategies and Aquaculture Waste. Proceedings of the First International Symposium on Nutritional Strategies in Management of Aquaculture Waste. University of Guelph, Guelph, pp. 21-35.

Li, M. H. and Robinson, E. H. 1996. Comparison of chelated zinc and zinc sulfate as zinc sources for growth and bone mineralization of channel catfish (Ictalurus punctatus) fed practical diets. Aquaculture 146, 237-243.

Maage, A. and Julshamn, K. 1993. Assessment of zinc status in juvenile Atlantic salmon (Salmo salar) by measurement of whole body and tissue levels of zinc. Aquaculture 117, 179-191.

Masumoto, T. 2002. Yellowtail, Seriola quinqueradiata. In: Webster CD, Lim C (eds). Nutrient Requirements and Feeding of Finfish for Aquaculture. CAB International. pp. 131-146.

NRC (National Research Council) .1993. Nutrient Requirements of Fish. National Academy Press, Washington, DC, USA.

Ogino, C. and Takeda, H. 1978. Requirement of rainbow trout for dietary calcium and phosphorus. Nippon Suisan Gakkaishi 44, 1019-1022.

Ogino, C., 1980. Requirements of carp and rainbow trout for essential amino acids. Nippon Suisan Gakkaishi 46, 171-174.

Satoh, S., Takeuchi, T. and Watanabe, T. 1987. Availability to rainbow trout of zinc in white fish meal and of various zinc compounds. Nippon Suisan Gakkaishi 53, 595- 599.

Satoh, S., Izume, K., Takeuchi, T. and Watanabe, T. 1987a. Availability to rainbow trout of zinc contained in various types of fish meals. Nippon Suisan Gakkaishi 53, 1861- 1866. 
Satoh, S., Tabata, K., Izume, K., Takeuchi, T. and Watanabe, T. 1987b. Effect of dietary tricalcium phosphate on availability of zinc to rainbow trout. Nippon Suisan Gakkaishi 53, 1199-1205.

Satoh, S., Porn-Ngam, N.K., Takeuchi, T. and Watanabe, T. 1996. Influence of dietary phosphorus levels on growth and mineral availability in rainbow trout. Fish. Sci. 62, 483-487.

Satoh, S., Takanezawa, M., Akimoto, A., Kiron, V. and Watanabe, T. 2002. Changes of phosphorus absorption from several feed ingredients in rainbow trout during growing stages of extrusion of soybean meal. Fish. Sci. 68, 325-331.

Scoot, W. B. and Croosman, E. J. 1975. Freshwater fishes of Canada. Fisheries Research Board of Canada, Ottawa. 966p.

Shitanda, K., Azuma, R. and Ukita, M.1979. Effect of phosphorus supplement to commercial diet on growth, feed efficiency, chemical component of serum and body with carp. Suisanzoshoku 27, 26-32 (in Japanese).

Takamatsu, C., Endoh, E., Hasegawa, T. and Suzuki, T. 1975. Effect of phosphate supplemented diet on growth of carp. Suisanzoshoku 23, 55-60 (in Japanese).

Watanabe, T., Pongmaneerat, J., Satoh, S. and Takeuchi, T. 1993. Replacement of fish meal by alternative protein sources in rainbow trout diets. Nippon Suisan Gakkaishi 59, 1573-1579.

Watanabe, T., Kiron, V. and Satoh, S. 1997. Trace minerals in fish nutrition. Aquaculture 151, 185207.

Watanabe, T., Aoki, H., Shimamoto, K., Hadzuda, M., Maita, M., Yamagata, Y., Kiron, V. and Satoh, S. 1998. A trial to culture yellowtail with non-fishmeal diets. Fish. Sci. 64, 505-512.

Wekell, J. C., Shearer, K.D. and Gauglitz, E.J. Jr. 1986. Zinc supplementation of trout diets: tissue indicators of body zinc status. Prog. Fish. Cult. 48, 205-212.

Yamaguchi, M. 1998. Role of zinc in bone formation and bone resorption. J. Trace Elem. Exp. Med. 11, 119-135. 